\section{Improved Transformation of Anthurium}

\author{
Maureen M.M. Fitch ${ }^{1,2}$ \\ Hawaii Agriculture Research Center, P.O. Box 100, Kunia, HI 96759
}

Terryl C.W. Leong, Xiaoling He, Heather R.K. McCafferty, Yun J. Zhu, and Paul H. Moore

Hawaii Agriculture Research Center, P.O. Box 100, Kunia, HI 96759

Dennis Gonsalves

Pacific Basin Agricultural Research Center (PBARC), ARS, USDA, 64 Nowelo Street, Hilo, HI 96720

Herb S. Aldwinckle

Cornell University, Geneva, NY 14456

Howard J. Atkinson

University of Leeds, Leeds, LS2 9JT, UK

Additional index words. Agrobacterium tumefaciens, genetic engineering, somatic embryogenesis

\begin{abstract}
Methods to increase transformation efficiency and yields of transgenic Anthurium andraeanum Linden ex. André hybrids were sought while effecting gene transfer for resistance to the two most important pests, bacterial blight (Xanthomonas axonopodis pv. dieffenbachiae) and nematodes (Radopholus similis and Meloidogyne javanica). Differentiated explant tissues, embryogenic calli, and comingled mixtures of the two were transformed with binary DNA plasmid constructs that contained a neomycin phosphotransferase II (nptII) selection gene with a nos promoter and terminator. Explants included $\approx 1$-cm long laminae, petioles, internodes, nodes, and root sections from light- and darkgrown in vitro plants. Bacterial blight resistance genes were NPR1 from Arabidopsis, attacin from Hyalophora cecropia, and T4 lysozyme from the T4 bacteriophage. For nematode resistance, rice cystatin and cowpea trypsin inhibitor genes were used. Cocultivation with Agrobacterium tumefaciens strains EHA105, AGLO, and LBA4404 ranged from 2 to 14 days. Over 700 independent, putatively transformed lines were selected with 5 and $20 \mathrm{mg} \cdot \mathrm{L}^{-1}$ geneticin (G418) for cultivars Midori and Marian Seefurth, respectively. Putative transgenic lines were selected 1 to 11.5 months, but on average 5.2 to 8.4 months, after cocultivation depending on the tissue type transformed. Significantly more embryogenic calli (one line per $5 \mathrm{mg}$ calli) produced transgenic lines than did explants (one line per $143 \mathrm{mg}$ explants $)(P<0.004)$ from $\approx 30 \mathrm{mg}$ of tissue. Calli grew selectively from all explant types, but the type of explant from which each selection was made was not recorded because root, internode, and petiole explants were difficult to discern by the time calli developed. Shoots formed 3 months after calli were transferred to light. Non-transgenic control and transgenic 'Marian Seefurth' formed flower buds in the greenhouse $\approx \mathbf{2 8}$ months after cocultivation. The plants resembled commercially grown plants from a private nursery. No non-transformed escapes were detected among the selections screened for NPTII by enzyme-linked immunosorbent assay and polymerase chain reaction (PCR). The selections were positive for transgenes as assayed by PCR and Southern hybridizations. Southern blots showed single-copy insertions of the NPR1 regulatory gene. The ability to produce large quantities of independent transgenic lines from embryogenic calli in a relatively short time period should enable researchers to evaluate the effectiveness of any transgene by screening numerous anthurium lines for improved performance.
\end{abstract}

Anthurium (Anthurium andraeanum Linden ex. André) hybrids are important tropical cut flowers that rank second after cymbidium orchids in the Dutch flower auction (CBI, 2007) and first in Hawaii floriculture (NASS, 2009). Cultivars with high flower productivity, preferred flower shapes and colors, long vase life, pest resistance, and vigorous plant growth are sought in breeding programs (Kamemoto and Kuehnle, 1996). Plants lacking one or more of these attributes often remain in production if the shortcomings are outweighed by attractiveness and/or desirable flower color. Genetic engineering could be used to improve one or more deficiencies.

Costs in anthurium production would decrease if susceptibility to the two most important pests, bacterial leaf blight, Xanthomonas axonopodis pv. dieffenbachiae, and nematodes, Radopholus similis and Meloidogyne javanica (Alvarez et al., 2006), were attenuated or eliminated. Most commercial cultivars are susceptible to both pests. Strong tolerance to bacterial blight in A. andraeanum hybrid cultivars was unknown (Alvarez et al., 2006) until recently (Elibox and Umaharan, 2007a, 2007b, 2008a, 2008b). Tolerance from other anthurium species has been incorporated into modern interspecific hybrids by breeding (Kamemoto and Kuehnle, 1996), but breeding is long-term, taking 8 to 14 years for the introduction of a new commercial cultivar (Kuehnle and Chen, 1994; T. Amore, unpublished results). Although breeding is ongoing to improve anthuriums for multiple traits including pest tolerance (Kamemoto and Kuehnle, 1996; T. Amore, unpublished results), genetic transformation of important but highly susceptible cultivars could provide a faster solution for growers.

Previously, transformation of anthurium was carried out for bacterial blight resistance using Agrobacterium tumefaciens strain LBA4404 (Hoekema et al., 1983) and two different tissue types, etiolated internodes (Chen and Kuehnle, 1996; Kuehnle and Chen, 1994; Kuehnle et al., 2001, 2004), and root sections (Chen et al., 1997). However, the efficiency of those protocols was low with $\approx 50$ independently transformed lines reported. Attacin and cecropin, lytic peptide genes, and their derivatives from Hyalophora cecropia the giant silkmoth (Jaynes et al., 1987), and the antibiotic resistance selection gene neomycin phosphotransferase II (nptII) in a pBI121 binary vector (Clontech, Mountain View, CA, http://www.clontech.com) were transformed into seven Hawaii cultivars, Rudolph, Paradise Pink, Tropic Flame, Anuenue, UH1060, Marian Seefurth, and Mauna Kea. Transgenic shoots were regenerated 12 to 18 months after cocultivation with yields of $5 \%$ to $20 \%$ of etiolated internodes per experiment (Chen and Kuehnle, 1996; Kuehnle and Chen, 1994; Kuehnle et al., 2001) and $1.3 \%$ of root explants (Chen et al., 1997). The total amount of tissue cocultivated and the number of transgenic lines selected were not reported in the etiolated internode and root studies. Two 'Paradise Pink' lines out of 13 lines transformed with a derivative of the cecropin gene showed increased tolerance to bacterial blight over the most tolerant industry standard, 'Kalapana', based on bioassays with bioluminescent bacteria (Kuehnle et al., 2004). Increased sensitivity to the bacterial pathogen was also observed in one transgenic line and two others were not significantly different from susceptible controls. Field data on the two tolerant lines and blight-resistant transgenic anthuriums were not reported.

Somatic embryogenesis from cultured whole leaf and petiole explants from in vitrogrown plants was previously reported for several Hawaiian anthurium lines, e.g., UH 780, 
UH 965, and UH 1060 (Kuehnle et al., 1992). In the present work, we report on a quicker, higher-yielding method for transforming anthuriums using embryogenic calli. Additionally, we improved efficiency of transformation of differentiated in vitro-grown tissues. Generation of large quantities of independent transgenic lines in a short time period should enhance evaluation of transgenes for anthurium improvement. Transformation was carried out with genes reported to improve bacterial resistance in other crops, lytic peptide genes (Jaynes et al., 1987) in apple (Ko et al., 2000) and anthurium (Kuehnle et al., 2004), overexpression of the Arabidopsis NPRl gene in Arabidopsis (Cao et al., 1998), the T4 lysozyme gene in potato (Düring et al., 1993), and attacin+T4 lysozyme genes in apple (Ko et al., 2002). Nematode resistance was sought using genes reported to improve resistance, rice cystatin in banana (Atkinson et al., 2004), and a dual construct, rice cystatin and cowpea trypsin inhibitor, in Arabidopsis (Urwin et al., 1998).

\section{Materials and Methods}

Plant material and tissue culture media. In vitro-grown plants of anthurium cultivars Midori and Marian Seefurth were purchased from a commercial tissue culture laboratory (Alphagenesis, Inc., Pepeekeo, HI). Both cultivars had been in culture for more than 5 years. The plants were used to generate explant tissues and embryogenic calli for use in transformation experiments. Embryogenesis was initiated from $\approx 1-\mathrm{cm}$ sections of lamina, petiole, internode, node, and root explants on several different media based on Murashige and Skoog salts (Murashige and Skoog, 1962; Table 1) in darkness at $26^{\circ} \mathrm{C}$. Subcultures were performed after calli were observed. Etiolated tissues were prepared by growing plant clusters on Medium \#1A (Table 1) in darkness at $26{ }^{\circ} \mathrm{C}$ as described by Chen and Kuehnle (1996). Green plants were grown under cool-white fluorescent

Table 1. Media for anthurium transformation.

\begin{tabular}{llc}
\hline Medium & \multicolumn{1}{c}{ Basal medium } & Growth regulators \\
\hline Medium \#1 & $\begin{array}{l}\text { Half-strength MS basal salts but containing full } \\
\text { micronutrients and }\end{array}$ & $2.2 \mu \mathrm{M}$ BA \\
& $0.4 \mathrm{mg} \cdot \mathrm{L}^{-1}$ thiamine & \\
& $25 \mathrm{mg} \cdot \mathrm{L}^{-1} \mathrm{NaFeEDTA}$ \\
& $100 \mathrm{mg} \cdot \mathrm{L}^{-1}$ myo-inositol & \\
& $3 \% \mathrm{sucrose}$ & \\
& $0.28 \%$ Gelrite & $0.9 \mu \mathrm{M}$ BA \\
Medium \#1A & Half-strength MS as in \#1 & None \\
Medium \#1A no BA & Half-strength MS as in \#1 & $2.2 \mu \mathrm{M}$ BA \\
Medium \#5 & MS basal salts and & $10.8 \mu \mathrm{M}$ NAA \\
& $0.4 \mathrm{mg} \cdot \mathrm{L}^{-1}$ thiamine & \\
& $25 \mathrm{mg} \cdot \mathrm{L}^{-1} \mathrm{NaFeEDTA}$ & \\
& $100 \mathrm{mg} \cdot \mathrm{L}^{-1}$ myo-inositol & $13.6 \mu \mathrm{M} 2,4-\mathrm{D}$ \\
Medium \#6 & $3 \%$ sucrose & $0.9 \mu \mathrm{M}$ BA \\
Medium \#7 & $0.28 \%$ Gelrite & $13.6 \mu \mathrm{M} 2,4-\mathrm{D}$ \\
Medium \#8 & $\mathrm{MS}$ basal salts, modified as in \#5 & $0.9 \mu \mathrm{M}$ BA
\end{tabular}

${ }^{\mathrm{z}}$ Modified from Chen et al., 1997.

$\mathrm{MS}=$ Murashige and Skoog; BA = benzylaminopurine; NAA = 1-naphthaleneacetic acid; 2,4-D = 2,4-dichlorophenoxyacetic acid. laboratory lights $\left(10 \mu \mathrm{mol} \cdot \mathrm{m}^{-2} \cdot \mathrm{s}^{-1}\right)$ in $200-\mathrm{mL}$ jars of Medium \#1A. Etiolated and light-grown differentiated tissues used for cocultivation consisted of explants of laminae, petioles, internodes, nodes, and roots. Explant tissues in each trial were mixtures of these different tissues. Regenerated plants were grown in Medium \#1A no benzylaminopurine (BA) in Magenta GA7 vessels (Phytotechnology Laboratories, Shawnee Mission, KS). The photoperiod in the laboratory was $14 \mathrm{~h}$ light/ $10 \mathrm{~h}$ dark, $26{ }^{\circ} \mathrm{C}$.

Kill curves. Kill curves for G418, the selective agent for the nptII resistance gene, were established for 'Marian Seefurth' embryogenic calli. It was assumed that one kill curve would suffice for both cultivars. Two experiments were compared. In Test 1 , initial callus weight was $\approx 15 \mathrm{mg}$ and three 2 - to 3 $\mathrm{mm}$-diameter pieces were placed on each plate. There were nine replicates per treatment and four geneticin concentrations, $0,20,50$, and $100 \mathrm{mg} \cdot \mathrm{L}^{-1}$. Test 2 was a repeat of Test 1. Replicate data were combined for callus diameter and fresh weight for Tests 1 and 2, averaged, and analyzed by analysis of variance (Statistix 7 for Windows, 2000).

Plasmids. Binary plasmid constructs were provided by collaborators $(\mathrm{H}$. Atkinson, University of Leeds, UK; K. Düring, Axara Consulting, Frechen, Germany; X. Dong, University of North Carolina; and H. Aldwinckle, Cornell University, NY). All of the bacterial blight resistance constructs contained nos/nptII as the selection gene in a pBI121 backbone (Clontech) except for that of NPR1. The NPR1 gene construct was described by Cao et al. (1997), the attacin gene construct was described by Ko et al. (2000), the attacin+T4 lysozyme gene construct was described by Ko et al. (2002), and the T4 lysozyme gene construct was described by Porsch et al. (1998).

The two nematode resistance gene constructs, p $\Delta 86$ GO CpTI (Urwin et al., 1998) and $\mathrm{p} \Delta 86 \mathrm{pB} 2 / \mathrm{ubi} 9$ (L. Wen, unpublished results), were also based on pBI121 vectors and received in EHA105 (Hood et al., 1993) and AGLØ (Lazo et al., 1991), respectively. The maize ubiquitin promoter UBI-1 in a cystatin construct described by Urwin et al. (1998) was replaced by the sugarcane polyubiquitin promoter $u b i 9$ (Wei et al., 1999) in the $\mathrm{p} \Delta 86$ pB2/ubi9 construct (L. Wen, unpublished results). The NPR1 gene construct was received in Agrobacterium tumefaciens EHA105 and LBA4404. Precipitated plasmids of the other bacterial blight resistance gene constructs containing attacin and T4 lysozyme genes were transformed into A. tumefaciens LBA4404 by the freeze-thaw method (Holsters et al., 1978).

Cocultivation of anthurium tissues with Agrobacterium tumefaciens. A loopful of Agrobacterium was grown overnight in $5 \mathrm{~mL}$ YEB $+25 \mathrm{mg} \cdot \mathrm{L}^{-1}$ kanamycin, diluted to $\mathrm{OD}_{600} 0.25$ to 0.3 (Bio-mini Spectrophotometer, Shimadzu, Columbia, MD), and incubated for 3 to $4 \mathrm{~h}$. Acetosyringone (AS) was added at $50 \mu \mathrm{M}$ for attacin and attacin $+\mathrm{T} 4$ lysozyme construct experiments. When the $\mathrm{OD}_{600}$ reached 0.8 to 0.9 , the tube was centrifuged for $10 \mathrm{~min}$ at $3000 \times \mathrm{g}$, the supernatant decanted, and fresh YEB and $50 \mu \mathrm{M}$ AS were added.

Approximately 0.5 to $5 \mathrm{~g}$ fresh weight of yellow embryogenic calli and/or 0.5 to $2.4 \mathrm{~g}$ fresh weight of explant tissues were cocultivated with each construct in Agrobacterium tumefaciens. A volume of $50 \mathrm{~mL}$ of bacterial suspension, $\mathrm{OD}_{600} \approx 0.6$ to 0.8 , was used for attachment with each batch of anthurium tissues.

Different types of plant material were used with different constructs in the transformation trials. Only explant tissues (differentiated in vitro-grown explants from light- and darkgrown plants) were used for the NPRI experiment. Only dark-grown embryogenic calli were cocultivated in the T4 lysozyme experiment. The attacin, attacin $+\mathrm{T} 4$ lysozyme, cystatin, and cystatin + cowpea trypsin inhibitor (CpTI) experiments were carried out using both light- and dark-grown explant tissues and embryogenic calli. Internodes, nodes, laminae, petioles, and roots from 4- to 10-month-old cultures and yellow embryogenic callus 4 to 7 months old were cut into 0.5 - to $1-\mathrm{cm}$ sections $(\approx 30 \mathrm{mg})$ and incubated with $A$. tumefaciens. While in suspension, the calli were diced into 3- to 4-mm pieces and pricked with a scalpel to increase the amount of wound surface for bacterial attachment. The mixtures were incubated at room temperature for $30 \mathrm{~min}$, blotted on sterile filter paper, placed on filter paper-lined Medium \#1 plates with or without $20 \mathrm{~mm} \mathrm{AS}$, and cocultivated for 2 to $14 \mathrm{~d}$ in the dark at room temperature.

Agrobacterium removal after transformation. When bacterial haloes surrounding explants and calli were $\approx 3 \mathrm{~mm}$ wider than the plant material, cocultivation was stopped. Explants and calli were washed five times with sterile distilled water and, in some experiments, 3 $\mathrm{mL} \cdot \mathrm{L}^{-1} \mathrm{PPM}^{\mathrm{TM}}$ (Plant Preservative Mixture, Phytotechnology Laboratories) followed by overnight soaking in the solution. Rinsed explant pieces and small callus clusters $\approx 3$ $\mathrm{mm}$ in diameter were plated onto $100-\mathrm{mm}$ petri dishes of Medium \#1 containing 250 or 500 
$\mathrm{mg} \cdot \mathrm{L}^{-1}$ cefotaxime (decontamination and recovery medium), 20 to 30 pieces per plate. Half of the attacin and attacin + T4 lysozyme gene cultures were cocultivated on Medium \#1 containing $20 \mathrm{~mm} \mathrm{AS}$, whereas the other half was on Medium \#1 without AS. Plates were incubated at $26{ }^{\circ} \mathrm{C}$ in the dark and checked every other day for 2 weeks for bacterial overgrowth and fungal contamination. Tissues were allowed to recover on Medium \#1 containing 250 to $500 \mathrm{mg} \cdot \mathrm{L}^{-1}$ cefotaxime until calli formed on cut edges or until organogenic growth was observed. After the cystatin experiments, recovery was limited to explants and mixtures only.

Selection of transformed lines. Cocultivated tissues were transferred to selection plates of Medium \#1 containing 250 or 500 $\mathrm{mg} \cdot \mathrm{L}^{-1}$ cefotaxime and 50 to $200 \mathrm{mg} \cdot \mathrm{L}^{-1}$ kanamycin or 5 to $100 \mathrm{mg} \cdot \mathrm{L}^{-1}$ geneticin. Tissues were subcultured monthly or bimonthly to fresh selection medium containing cefotaxime for $\approx 3$ months after which time cefotaxime was omitted unless the Agrobacterium regrew. Embryogenic calli that grew to $\approx 1 \mathrm{~cm}$ in diameter were diced into 2- to 3-mm diameter pieces and subcultured to eliminate non-transgenic sectors. Explant tissues that developed new shoots were diced into $\approx 2-\mathrm{mm}$ pieces to expose the tissues to the selection medium and minimize escapes. Selectively growing yellow calli from explants and embryogenic calli were removed to fresh selection plates, up to eight per plate, and grown in the dark. If the callus grew in 1 or 2 months, it was divided and plated on three selection plates to minimize loss resulting from contamination. Efficiency of transformation was equated with frequency of transformation for cultivar, tissue type, light or dark treatment, AS treatment, and construct and was calculated as the number of selected lines per $100 \mathrm{mg}$ fresh weight of cocultivated tissues in the experiment. The average recovery and selection times after cocultivation were recorded for each treatment to identify the quickest method.

Plant regeneration. When selectively growing calli grew to $1 \mathrm{~cm}$ in diameter, sections were transferred to fresh medium free of the selection compound and regenerated under diffuse cool-white fluorescent light $(10 \mu \mathrm{mol}$. $\left.\mathrm{m}^{-2} \cdot \mathrm{s}^{-1}\right)$. Shoots $\approx 0.5$ to $1 \mathrm{~cm}$ tall with one to three nodes were grown in Medium \#1A or \#1A without BA (Table 1) in Magenta GA7 boxes. Young leaves and shoot tips were sampled for enzyme-linked immunosorbent assay (ELISA), PCR assays, and Southern hybridizations. When roots formed, the plants were shipped to the field test site. A number of PCR and Southernpositive plants was potted in Sunshine \#4 potting medium (Sungro Horticulture, Canada). These plants were maintained in the greenhouse and observed for abnormal growth compared with non-transgenic control plants. Daytime temperature ranged from 24 to $29{ }^{\circ} \mathrm{C}$ and nighttime temperature ranged from 22 to $26^{\circ} \mathrm{C}$.

Confirmation of transformants. Selectively growing tissues were subjected to NPTII ELISA, PCR, and Southern hybridization using standard protocols to identify the nptII marker gene and/or target transgenes.

Enzyme-linked immunosorbent assay. NPTII ELISA was used to assay calli, shoots, and leaves according to the manufacturer's instructions (Agdia, Elkhart, IN). Approximately $100 \mathrm{mg}$ of the selectively growing clusters, regenerated shoot tips, or young leaves were tested for NPTII activity. ELISA readings were recorded on an MRX Dynex microtiter plate reader (Chantilly, VA) that detected protein concentrations that were extrapolated for the amount of NPTII in the samples and compared with the positive control provided in the kit.

Polymerase chain reaction analysis. Genomic DNA was extracted from $50 \mathrm{mg}$ of selectively growing calli or young leaf and shoot tissues from regenerated in vitro-grown plants using the modified SDS method described by Lin et al. (2001). The PCR reactions were performed in $25-\mu \mathrm{L}$ volumes consisting of $1 \mu \mathrm{L}(5 \mathrm{ng})$ total DNA, $1 \mu \mathrm{L}$ of each primer $(1 \mu \mathrm{M}), 2.5 \mu \mathrm{L}$ dNTPs $(0.2 \mathrm{~mm}$ of each dNTP), $5 \mu \mathrm{L} 5 \times$ Taq buffer (Promega, Madison, WI), $0.5 \mathrm{U}$ Go Taq polymerase (Promega, Madison, WI), and $13 \mu \mathrm{L} \mathrm{H}_{2} \mathrm{O}$. The PCR conditions were as follows: $3 \mathrm{~min}$ at $94{ }^{\circ} \mathrm{C}$, then 30 cycles of $94{ }^{\circ} \mathrm{C}$ for $30 \mathrm{~s}, 55^{\circ} \mathrm{C}$ for $45 \mathrm{~s}, 72^{\circ} \mathrm{C}$ for $45 \mathrm{~s}$, and finally, $7 \mathrm{~min}$ at $72{ }^{\circ} \mathrm{C}$. Primer pairs used in this study are listed in Table 2.

Southern hybridization. Tissue culturegrown non-transformed plants regenerated from embryogenic calli and PCR-positive transgenic plants were analyzed by Southern hybridization. Genomic DNA was extracted from $\approx 80$ to $100 \mathrm{mg}$ of fresh in vitro-grown young leaves and shoots using the same method used before PCR (Lin et al., 2001). DNA $(20 \mu \mathrm{g})$ was digested with $\mathrm{BamHI}$, which has a single restriction site in the T-DNA region of the plasmid. Digested DNA was separated on a $1 \%$ agarose gel and alkali-blotted onto a Hybond $\mathrm{N}+$ membrane (Amersham, UK) according to the manufacturer's instructions. The PCR amplification product, a 650-bp fragment of the NPRl gene, was labeled with AlkPhos Direct (Amersham) according to the manufacturer's instructions and used as a chemifluorescent probe. Hybridization and detection were performed according to the manufacturer's protocol (Amersham).

\section{Results}

Embryogenic callus culture establishment. Laminae, petioles, nodes, internodes, roots, and hard yellow-green tissues at the shoot bases of 'Marian Seefurth' and 'Midori' micropropagated plants developed embryogenic calli (Fig. 1) on several media (Table 1). Bright yellow embryogenic calli developed from explants on Media \#1, 5, 7, and 8, formulations that were variations of half-strength MS and MS media. Within 2 weeks of culture, the nodal and internodal tissues developed smooth, bright yellow callus masses on Medium \#1 containing $2.2 \mu \mathrm{M}$ BA, whereas the hard yellow-green tissues cultured on Medium \#6 containing 2,4dichlorophenoxyacetic acid (2,4-D) turned brown and did not develop further. The browning masses were transferred to Medium \#1 and in 1 month bright yellow embryogenic calli emerged from some of the brown tissues. Explants on Medium \#7 that contained both 2,4-D and BA developed embryogenic calli. 'Marian Seefurth' cultures produced larger amounts of embryogenic calli earlier than did 'Midori' cultures. Lamina tissues cultured on Media \#5 and \#8, MS containing 1-naphthaleneacetic acid and BA, formed hard, yellow calli, but many of the calli regenerated roots during the second month of culture on the same medium. The most vigorous callus growth was on Medium \#1 that was selected for all subsequent experiments. Embryogenic calli increased in mass when subcultured monthly on Medium \#1 and were grown in darkness at $26^{\circ} \mathrm{C}$. Media \#1A and \#1A no BA were shoot and root growth media, respectively. Plants were grown in Medium \#1A no BA for the field test.

Kill curves. A larger amount of 'Marian Seefurth' embryogenic callus was generated early in the experiment compared with 'Midori'; therefore, a kill curve was established using only 'Marian Seefurth'. The combined data indicated that the lowest concentration of geneticin, $20 \mathrm{mg} \cdot \mathrm{L}^{-1}$, inhibited embryogenic callus growth (measured by an increase in weight) after 1 month of culture as much as the higher concentrations, 50 and $100 \mathrm{mg} \cdot \mathrm{L}^{-1}$ (data not shown).

Selection: tissue types. Selection results varied between the experiments because different gene constructs, Agrobacterium strains, tissue types, and treatments were used (Table 3). Transformation efficiency identified the best treatments. Results are presented in two of the categories, tissue types, and use of acetosyringone.

In the NPRI experiment (Table 3), some of the light- and dark-grown cocultivated explants (laminae, petioles, nodes, internodes, and root sections) developed selectively growing calli, but tissue type from which each line grew was not recorded. By the time calli were observed, it was difficult to differentiate between the dark brown root,

Table 2. Polymerase chain reaction primer sequences for transgene detection.

\begin{tabular}{|c|c|c|}
\hline Transgene & Forward primer & Reverse primer \\
\hline$n p t \mathrm{II}$ & $5^{\prime}$-CCC CTC GGT ATC CAA TTA GAG-3' & $5^{\prime}$-CGG GGG GTG GGC GAA GAA CTC CAG-3' \\
\hline Cystatin & $5^{\prime}$-CAC CGA GCA CAA CAA GAA GG-3' & $5^{\prime}$-CTG GCA TCG ACA GGC TTG AA-3' \\
\hline NPR1 & 5' - GCC GAT GTC AAC CAT AGG-3' & $5^{\prime}-$ CTC AGC AGT GTC GTC TTC-3' \\
\hline Attacin & $5^{\prime}$-GCT ATC GGT TCC GTA GAC TT-3' & 5'-GAG AGT AGT CGT TGC GAT TG-3' \\
\hline T4 lysozyme & 5'-CAC TAT TGG CAT CGG TCA T-3' & $5^{\prime}$-GTT AAC TGC TGC TTC ATC C-3' \\
\hline
\end{tabular}




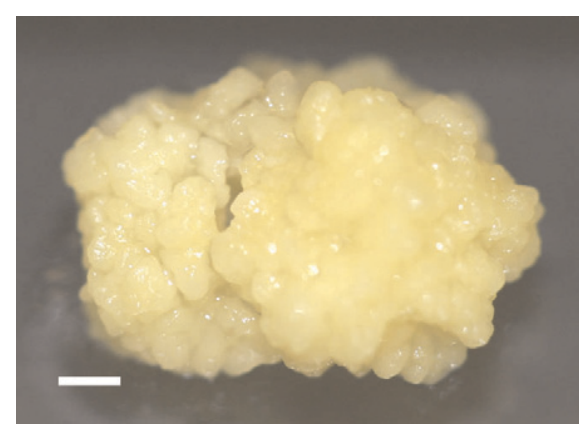

Fig. 1. Embryogenic anthurium 'Marian Seefurth' callus. Bar $=1 \mathrm{~mm}$

petiole, node, and internode sections. This was the only experiment in which two different Agrobacterium strains were used for the same construct. All of the EHA105 cocultivated cultures were lost because the bacteria rapidly overgrew the tissues in $4 \mathrm{~d}$, were difficult to eliminate because they regrew from washed explant tissues on cefotaxime, and appeared to kill the tissues. After 5 or $11 \mathrm{~d}$ of cocultivation with LBA4404 and 1 month of recovery (Table 3 ), only actively growing explants, calli, or enlarged organogenic structures were moved to Medium \#1 containing 250 or $500 \mathrm{mg} \cdot \mathrm{L}^{-1}$ cefotaxime and 50 or $100 \mathrm{mg} \cdot \mathrm{L}^{-1}$ kanamycin (K50 or K100) for 2 months, but kanamycin was replaced by geneticin at $20,30,50$, and/or $100 \mathrm{mg} \cdot \mathrm{L}^{-1}$ (G20, G30, G50, G100) because clearly defined, selectively growing sectors of bright yellow embryogenic calli were not evident on kanamycin media. Some of the explant tissues that remained on recovery medium for 3 months developed calli or organogenic shoots and were placed on geneticin media. Selectively growing calli and organs $1 \mathrm{~cm}$ long that were diced into 2- to 3-mm diameter pieces and subcultured to geneticin higher than $\mathrm{G} 20$ bleached in $\approx 1$ month. Approximately 40 'Marian Seefurth' (37\%) and nearly all 'Midori' selections were bleached and lost. Partly bleached 'Marian Seefurth' lines subcultured from higher concentrations to G20 resumed growth but no 'Midori' calli grew until transfer to G5 in which two lines developed yellow calli.

There were approximately four times as many selectively growing NPRI lines from light-grown compared with dark-grown explants, 3.4 lines/100 $\mathrm{mg}$ fresh weight versus 0.8 lines $/ 100 \mathrm{mg}$ fresh weight, respectively, despite the early losses to bleaching. Approximately equal numbers of light- and dark-grown lines were bleached. The yield of 'Midori' was 34 times less than 'Marian Seefurth'. The average recovery period for light-grown explants was approximately 2.5 weeks longer than for dark-grown explants, 2.4 months versus 1.8 months.

In the cystatin and cystatin + CpTI experiments, where only dark-grown tissues, etiolated explants, and embryogenic calli were used, cocultivation times differed because the constructs were in different Agrobacterium strains. Cocultivation was stopped after 2 and $5 \mathrm{~d}$ for the cystatin + CpTI construct in
EHA105 because, like in the NPR1 experiment, bacterial growth became too heavy. AGLØ grew more slowly like LBA4404 in the NPR1 experiment; thus, cocultivation time for cystatin was $14 \mathrm{~d}$. In addition, cystatin trials included mixtures of comingled explants and embryogenic calli. Explants and mixtures recovered for at least 3 months, whereas calli recovered for 1 month before selection. Embryogenic calli and callused explants were selected on K50 for 1.5 months then subcultured to K100, K200, G20, G50, or G100 for 1 month. As observed with the NPR1 selections, because selective growth on kanamycin was difficult to recognize, it was replaced with geneticin. Calli became bleached on G50 and G100 media and 29 isolates, most of which were selected from cocultivated calli, were lost. G20 was used for all subsequent selections with monthly subculturing. A total of 53 'Marian Seefurth' cystatin transformants was regenerated (Table 3). Approximately the same frequency of lines was generated from embryogenic calli (3.4 lines/100 mg fresh weight) and dark-grown mixtures of etiolated tissues and calli (3.2 lines/100 mg fresh weight) compared with a lower number of transformants from dark-grown, etiolated explant tissues (0.6 lines/100 mg fresh weight).

Analysis of variance (ANOVA) data (Table 4) taken 7 months after cocultivation in the cystatin experiment show that 'Marian Seefurth' yielded significantly more lines from embryogenic yellow calli, $18.7 \%$ or 5.6 lines/ $100 \mathrm{mg}$ fresh weight, compared with the mixture of embryogenic calli and etiolated explant pieces, $8.3 \%$ or 2.5 lines/100 $\mathrm{mg}$ fresh weight, and to dark-grown explants alone, $0.67 \%$ or 0.2 lines $/ 100 \mathrm{mg}$ fresh weight at $P<$ 0.004 . Yield from the mixture was not significantly different from that of explants alone. The ANOVA data differ from final tallies for cystatin selections (Table 3 ) because callus selections were recorded 1 year after the ANOVA data when more lines were discovered or lost.

The cystatin + CpTI transformant efficiency and yield were lower than that for cystatin transformants (Table 3). 'Marian Seefurth' yielded approximately the same number of selections, 0.8 lines/100 mg fresh weight and 1.2 lines $/ 100 \mathrm{mg}$ fresh weight from calli and dark-grown mixtures of explants and calli, respectively (Table 3). Unlike NPRI results, no selections grew from dark-grown explants. Only one selection was recovered from 'Midori' after the geneticin concentration was lowered from 20 to $5 \mathrm{mg} \cdot \mathrm{L}^{-1}$.

Selection: acetosyringone for Agrobacterium treatment and cocultivation. An experiment using AS in Agrobacterium growth and cocultivation media showed similar results for attacin and attacin $+\mathrm{T} 4$ lysozyme constructs transformed into explant tissues and embryogenic calli (Table 3). Transformation of both constructs used Agrobacterium strain LBA4404 and cocultivation period was $11 \mathrm{~d}$. Explant tissues from light-grown plants were the same for both constructs, but dark-grown mixtures were used for attacin, whereas explants only were used for attacin $+\mathrm{T} 4$ lysozyme transformation. All explants and mixtures were allowed to recover until embryogenic calli became visible on cut surfaces of explants. In this experiment, the recovery step was eliminated for embryogenic calli; the calli were plated directly onto G20 medium after cocultivation. Several of the explant only cultures neither developed embryogenic calli nor transgenic lines. For attacin, 'Marian Seefurth' light-grown explants + AS and 'Midori' lightgrown explants \pm AS did not produce transgenic lines. For attacin + T4 lysozyme, 'Marian Seefurth' dark-grown explants \pm AS and 'Midori' dark-grown explants \pm- AS did not produce transgenic lines (Table 3 ).

Acetosyringone treatment did not appear to be detrimental, but it was not necessary for high transformation efficiency (Table 3). 'Marian Seefurth' light-grown explants that recovered for 2.4 months produced 3.4 lines/ $100 \mathrm{mg}$ fresh weight (NPR1 without AS), equivalent to 'Marian Seefurth' dark-grown mixtures and embryogenic calli, 3.2 to 3.6 lines/100 mg fresh weight after 1 month of recovery (cystatin without AS) or no recovery on G20 (attacin + T4 lysozyme without AS). Transformation efficiency with AS was a little higher for calli and callus/explant mixtures, 4.2 and 4.4 lines/100 $\mathrm{mg}$ fresh weight (attacin), but the highest efficiency, 9 lines/100 mg fresh weight for T4 lysozyme without AS, indicated that neither the recovery step for calli nor AS were required. Explant tissues, whether light-grown, dark-grown, or mixtures, produced transformants if calli were allowed to form before selection; however, the recovery period added time to the total selection period. The quickest selections, averaging 2 to 3 months after cocultivation, were for 'Marian Seefurth' calli with or without AS in the attacin + T4 lysozyme experiment and for 'Marian Seefurth' mixtures without AS in the attacin experiment (Table 3). The latter treatment included 0.8 months recovery time for the comingled explants.

Approximately $76 \%$ of the 'Marian Seefurth' transgenic lines were generated from embryogenic calli cocultivated with or without AS and with or without a recovery period (Table 3). Because embryogenic calli were more readily produced compared with darkgrown or light-grown explants, these tissues were the most highly used. On a per-weight basis of tissues cocultivated, however, explant tissues, especially light-grown ones, were, in some cases, as productive as embryogenic calli.

Transgenic 'Midori' lines in the NPR1, cystatin, and cystatin + CpTI experiments were selected from explants and mixtures that were allowed to recover after cocultivation (Table 3). Growth during post-cocultivation recovery of transgenic sectors of this cultivar presumably allowed survival in highly stringent G20 selection. In some cases, selective growth occurred on G20, but in most others, transgenic sectors were not observed until selection pressure was reduced to G5.

Overall, embryogenic calli were the most productive tissues for anthurium transformation (Table 3). Combining all transformation frequency data regardless of AS treatments, the average efficiency was 1.27 lines $/ 100 \mathrm{mg}$ 


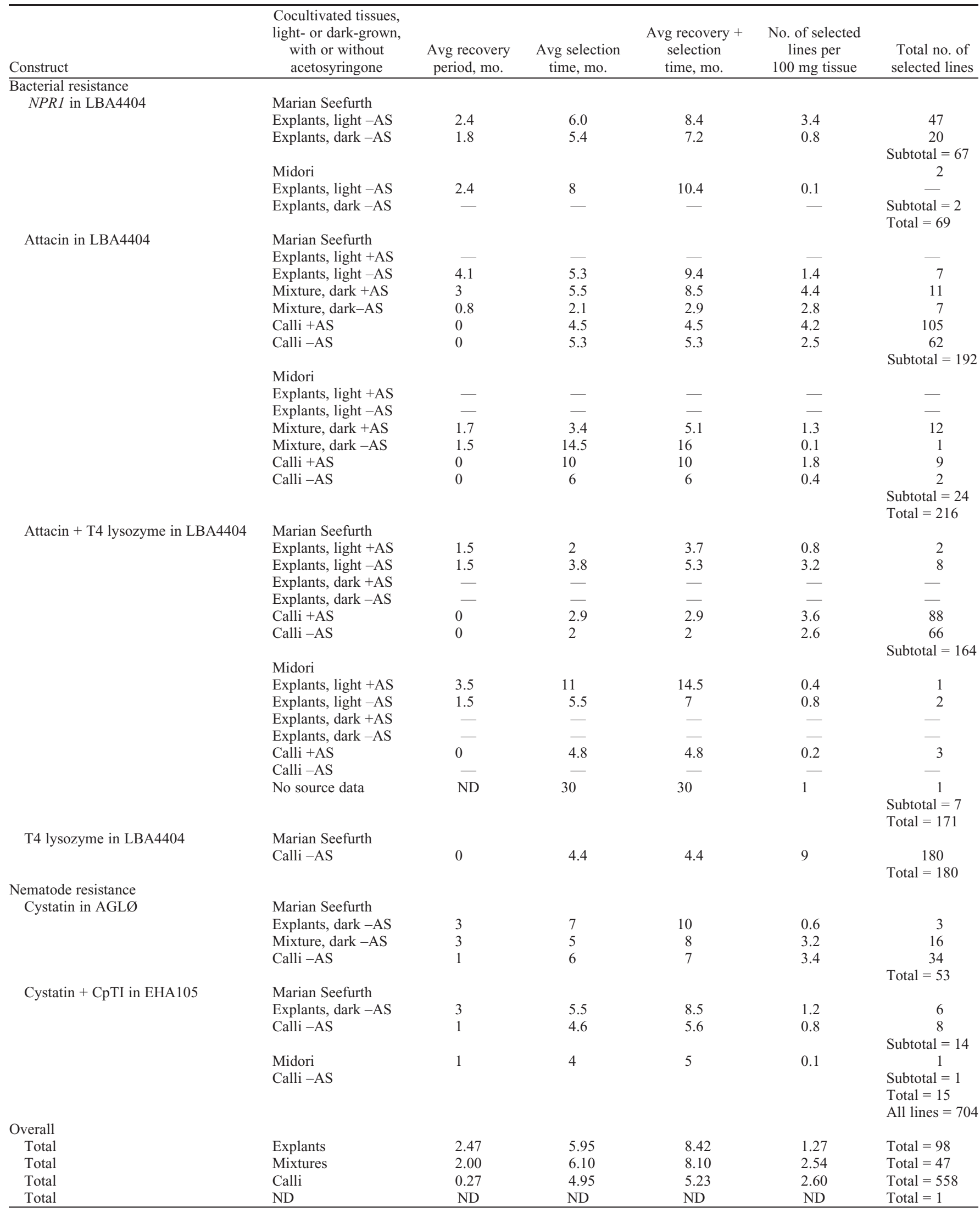

$\mathrm{AS}=$ acetosyringone; mixture $=$ mixture of explants and calli $\mathrm{ND}=$ no data.

fresh weight of explants, 2.54 lines $/ 100 \mathrm{mg}$ fresh weight of mixtures, and 2.60 lines/100 $\mathrm{mg}$ fresh weight of calli. Embryogenic calli produced selectively growing lines in the shortest average length of time. The compiled average for all experiments was embryogenic calli selected in 5.23 months after cocultivation with or without AS and recovery, whereas
3 more months were required for selection of mixtures and explant tissues with or without $\mathrm{AS}$ and with recovery, 8.10 and 8.42 months, respectively. 
Resistance gene confirmation: enzymelinked immunosorbent assay and polymerase chain reaction. Randomly selected 'Marian Seefurth' lines that were transformed with the cystatin construct were positive for NPTII activity with the ELISA test (data not shown). The NPTII enzyme concentration range detected, 4 to $12 \mathrm{ng} \cdot \mathrm{mL}^{-1}$, suggested that the selection gene was expressed in approximately the same range for all of the anthurium selections. Selected lines transformed with the NPRI and attacin constructs were all PCRpositive for $n p t I I$ (Figs. 2 and 3). These data indicate that there were no escapes from selection with G20 for 'Marian Seefurth' and 'Midori'. All 30+ NPRI lines tested by PCR

Table 4. Analysis of variance for transformation of 'Marian Seefurth' embryogenic calli versus explant tissues with a rice cystatin gene.

\begin{tabular}{lrrrr}
\hline Source & df & F & \multicolumn{2}{c}{$P$} \\
\hline REP & 9 & 0.93 & & 0.5253 \\
TRT & 2 & 7.78 & & 0.0037 \\
A*B & 18 & & & \\
Total & 29 & & Mean yield & Homogeneous groups \\
\hline TRT & & $5.6000=18.7 \%$ & I \\
Yellow calli & & $2.5000=8.3 \%$ & $\ldots$. I \\
Dark-grown mixture of calli and etiolated explants & $0.2000=0.67 \%$ & $\ldots$ I \\
Dark-grown explants & & & & \\
\hline
\end{tabular}

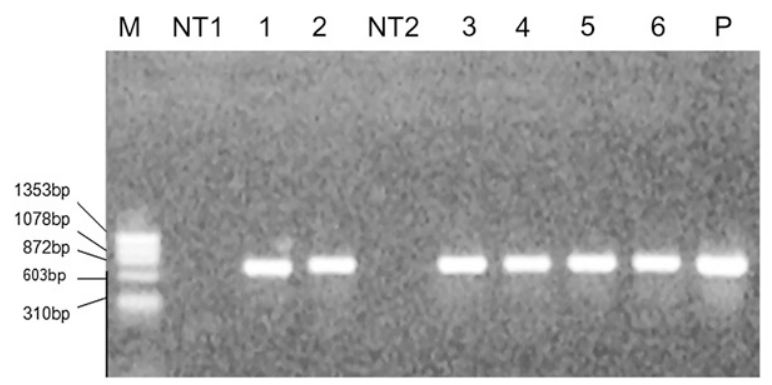

Fig. 2. nptII polymerase chain reaction, attacin construct. $\mathrm{M}=\Phi \mathrm{X} 174 \mathrm{DNA} / \mathrm{Hae} I \mathrm{II}$ molecular weight markers. NT $1=$ non-transformed 'Midori' control. Lanes 1 and $2=$ 'Midori' transformants AT- 25 and AT-39. NT2 = non-transformed 'Marian Seefurth' control. Lanes 3 to $6=$ 'Marian Seefurth' selections, AT-19, AT-34, AT-35, AT-36. P = attacin plasmid.
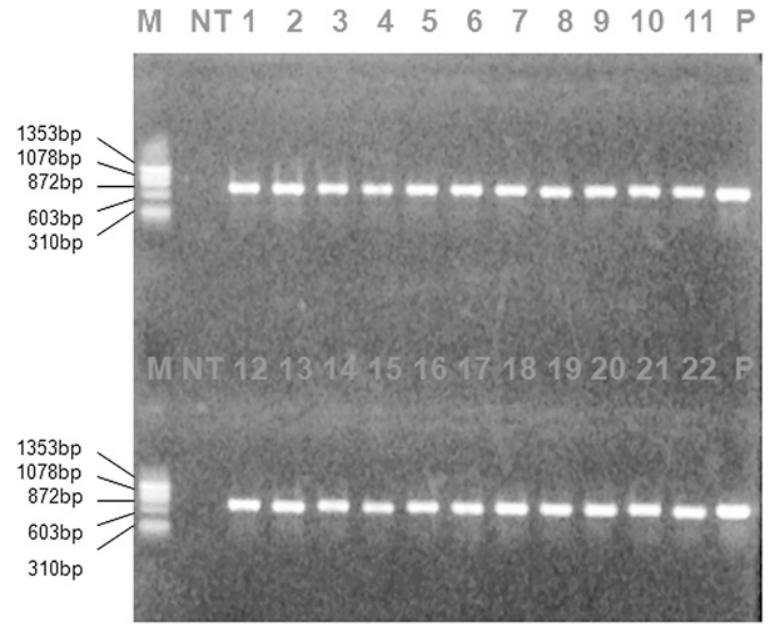

Fig. 3. nptII polymerase chain reaction, NPRI construct. $\mathrm{M}=\Phi \mathrm{X} 174 \mathrm{DNA} /$ HaeIII molecular weight markers. NT $=$ non-transformed 'Marian Seefurth' controls. Lanes 1 to $22=$ 'Marian Seefurth' selections, NPR1-42-1-1, NPR1-42-3-1, NPR1-39-3-1, NPR1-24-3, NPR1-31-1, NPR1-39-3, NPR149-3, NPR1-49-3B, NPR1-54-1, NPR1-57-1, NPR1-47-1-4, NPR1-69-1-1, NPR1-10-4, NPR1-67-1, NPR1-42-1-2, NPR1-63-1, NPR1-68-1-1, NPR1-42-1-9, NPR1-31-4-2, NPR1-22-2, NPR1-29-1, NPR1-70-1B. $\mathrm{P}=$ NPR1 plasmid. insertion into the anthurium genome. Three lines contained single-copy insertions of different sizes and the fourth line appeared to be equal in size to the third line; thus, NPR1-49-3 and NPR1-49-3B are probably identical. They were suspected to be the same clone because they originated from the same callus clump but were discovered on different dates, hence the "B" suffix for the line isolated later. Both lines survived bacterial blight screening bioassays in the greenhouse (L. Keith, unpublished results).

All $50+$ transgenic lines, randomly selected and assayed in this study, were positive in NPTII ELISA, PCR, and/or Southern hybridizations, showing that the selection system is effective.

\section{Discussion}

Genetic improvement of anthurium, a slowgrowing floriculture crop, would benefit from quicker, highly efficient gene transfer methods. In this study, six different gene constructs, two for nematode resistance and four for bacterial blight resistance, were used to transform 'Marian Seefurth' and 'Midori' to improve cultivars important to the Hawaii industry. Cocultivation of embryogenic calli, etiolated explant tissues, light-grown explants, and mixtures of tissue types resulted in significantly higher yields of independently transformed lines from calli.

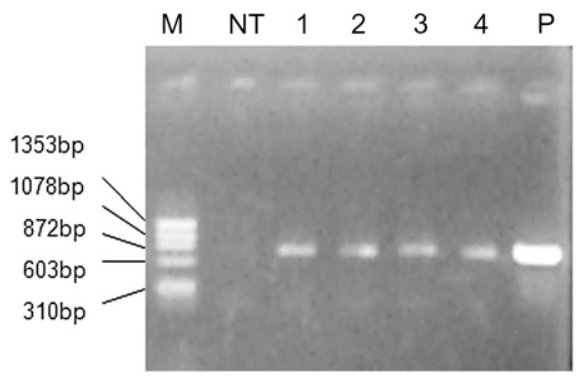

Fig. 4. Attacin polymerase chain reaction, four lines. $\mathrm{M}=\Phi \mathrm{X} 174 \mathrm{DNA} / \mathrm{Hae} \mathrm{III}$ molecular weight markers. NT $=$ non-transformed 'Marian Seefurth' control. Lanes 1 to $4=$ 'Marian Seefurth' selections, AT-19, AT-34, AT-35, AT-36. $\mathrm{P}=$ attacin plasmid.

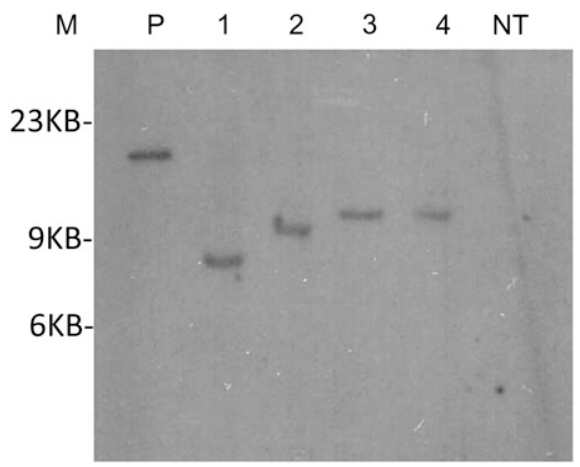

Fig. 5. $N P R 1$ gene Southern hybridization. $\mathrm{M}=\lambda$ DNA/HindIII molecular weight markers. $\mathrm{P}=$ linearized NPR1 plasmid. Lanes 1 to $4=$ 'Marian Seefurth' selections, NPR1-29-1, NPR1-31-1, NPR1-49-3, NPR1-49-3B. NT = non-transformed 'Marian Seefurth' control. 
Embryogenic calli were readily generated from in vitro-grown green plant tissues in 3 months. A shorter average time period for recovery of transgenic lines, 5.2 months for embryogenic calli and 8.4 months for explants versus 12 to 18 months for etiolated internodes and root explants in the earlier work (Chen et al., 1997, Chen and Kuehnle, 1996; Kuehnle and Chen, 1994; Kuehnle et al., 2001), was achieved. Higher average transformation efficiency, 1.27 lines/100 mg fresh weight of explant tissues, 2.54 lines $/ 100 \mathrm{mg}$ fresh weight of mixtures, and 2.60 lines/100 fresh weight of calli versus 0.04 lines $/ 100 \mathrm{mg}$ fresh weight of root explants (Chen et al., 1997) and 0.17 to 0.67 lines/100 $\mathrm{mg}$ fresh weight of etiolated internode explants (Kuehnle et al., 2001) and greater number of selected lines $(\approx 700$ versus $\approx 50)$, make this protocol useful for future transformation projects. We calculated transformation frequencies for the etiolated internode and root explant experiments in the earlier work by using $30 \mathrm{mg}$ fresh weight for $1-\mathrm{cm}$ explant tissues and extrapolated transformation percentage data to number of lines per $100 \mathrm{mg}$ fresh weight cocultivated to be able to compare our data with those in the published reports.

In some of our experiments, transgenic anthurium lines were selected as early as 2 weeks after cocultivation of embryogenic calli. The differences in efficiency and selection length may have resulted, in part, from the cultivars transformed, but other factors probably contributed, for example, the large number of trials conducted, because so many constructs were used and surely led to improved skill. Embryogenic calli and prolonged cocultivation likely allowed for increased Agrobacterium attachment and incidences of T-DNA transfer. Agrobacterium tumefaciens strains LBA4404 and AGLØ allowed longer cocultivation times with fewer removal/ regrowth problems compared with EHA105. Additionally, although we showed that embryogenic calli exposed to selection immediately after cocultivation yielded a high of nine transgenic lines/100 mg fresh weight, some explant tissues that formed callus before selection equaled embryogenic calli in transformation frequency. Kuehnle et al. (2001) cocultivated etiolated internodes for $3 \mathrm{~d}$ and placed explants onto selection medium immediately. Longer cocultivation time and recovery periods for callus development could have improved transformation efficiency in the earlier studies.

Our data are based on only two cultivars, Marian Seefurth and Midori, that were recommended by the Hawaii anthurium industry, but we are confident that other cultivars can be readily transformed with this protocol because several cultivars were reported to develop embryogenic calli (Kuehnle et al., 1992) and our own work with several other cultivars corroborates the report (M. Fitch, unpublished results). It is imperative that kill curves be developed for each cultivar. 'Marian Seefurth' non-transgenic control and Southern-positive plants appeared normal, formed flower buds 28 months after cocultivation, and resembled commercially grown plants from a private nursery (M. Fitch, unpublished results). Data from $\approx 700$ selections were presented but $\approx 150$ more were produced in a separate study in our group (H. McCafferty, unpublished results). A total of 466 lines was sent to the test site for bioassays in greenhouse/shadehouse conditions where experiments are still ongoing.

Based on the results of six genes transferred to two cultivars using different tissues, we conclude that the best anthurium tissues to transform are embryogenic calli on Medium \#1 using LBA4404 or AGL $\varnothing$ cocultivation for $\approx 10$ to $14 \mathrm{~d}$. Selection is recommended using G418 concentrations based on kill curve results for individual cultivars. The improvement in selection time and efficiency using embryogenic calli allows for high-throughput transformation in which attributes like pest resistance and improvement in quality depend on the chance good fortune of inserted gene location.

\section{Literature Cited}

Alvarez, A.M., P.J. Toves, and T.S. Vowell. 2006. Bacterial blight of anthuriums: Hawaii's experience with a global disease. Feb. 2006. <http:// www.apsnet.org/online/feature/anthurium/>.

Atkinson, H.J., S. Grimwood, K. Johnston, and J. Green. 2004. Prototype demonstration of transgenic resistance to the nematode Radopholus similis conferred on banana by a cystatin. Transgenic Res. 13:135-142.

Cao, H., J. Glazebrook, J.D. Clarke, S. Volko, and X. Dong. 1997. The Arabidopsis NPR1 gene that controls systemic acquired resistance encodes a novel protein containing ankyrin repeats. Cell 88:57-63.

Cao, H., X. Li, and X. Dong. 1998. Generation of broad-spectrum disease resistance by overexpression of an essential regulatory gene in systemic acquired resistance. Proc. Natl. Acad. Sci. USA 95:6531-6536.

CBI. 2007. Market information database. <http:// www.cbi.eu>.

Chen, F.-C. and A.R. Kuehnle. 1996. Obtaining transgenic Anthurium through Agrobacteriummediated transformation of etiolated internodes. J. Amer. Soc. Hort. Sci. 121:47-51.

Chen, F.-C., A.R. Kuehnle, and N. Sugii. 1997. Anthurium roots for micropropagation and Agrobacterium tumefaciens-mediated gene transfer. Plant Cell Tiss. Org. Cult. 49:71-74.

Düring, K., P. Porsch, M. Fladung, and H. Lörz. 1993. Transgenic potato plants resistant to the phytopathogenic bacterium Erwinia carotovora. Plant J. 3:587-598.

Elibox, W. and P. Umaharan. 2007a. A green fluorescent protein-based screening method for identification of resistance in anthurium to systemic infection by Xanthomonas axonopodis pv. dieffenbachiae. Plant Pathol. 56:819-827.

Elibox, W. and P. Umaharan. 2007b. The influence of systemic resistance to the bacterial blight pathogen Xanthomonas axonopodis pv. dieffenbachiae in Anthurium andraeanum (Hort.). Sci. Hort. 115:76-81.

Elibox, W. and P. Umaharan. 2008a. A quantitative screening method for the detection of foliar resistance to Xanthomonas axonopodis pv. dieffenbachiae in anthurium. Eur. J. Plant Pathol. 121:35-42.

Elibox, W. and P. Umaharan. 2008b. Genetic basis of resistance to systemic infection by Xanthomonas axonopodis pv. dieffenbachiae in anthurium. Phytopathology 98:421-426.

Hoekema, A., P.R. Hirsch, P.J.J. Hooykaas, and R.A. Schilperoort. 1983. A binary plant vector strategy based on separation of vir- and T-region of the Agrobacterium tumefaciens Ti-plasmid. Nature 303:179-180.

Holsters, M., D. de Waele, A. Depicker, E. Messens, M. van Montagu, and J. Schell. 1978. Transfection and transformation of Agrobacterium tumefaciens. Mol. Gen. Genet. 163:181-187.

Hood, E.E., S.B. Gelvin, L.S. Melchers, and A. Hoekema. 1993. New Agrobacterium helper plasmids for gene transfer to plants. Transgenic Res. 2:208-218.

Jaynes, J.M., K.G. Xanthopoulos, L. DestephanoBeltran, and J.H. Dodds. 1987. Increasing bacterial disease resistance in plants utilizing antibacterial genes from insects. Bioessays 6:263-270.

Kamemoto, H. and A.R. Kuehnle. 1996. Anthurium breeding in Hawaii. University of Hawaii Press, Honolulu, HI.

Ko, K., J.L. Norelli, J.-P. Reynoird, H.S. Aldwinckle, and S.K. Brown. 2002. T4 lysozyme and attacin genes enhance resistance of transgenic 'Galaxy' apple against Erwinia amylovora. J. Amer. Soc. Hort. Sci. 127:515-519.

Ko, K., J.L. Norelli, J.-P. Reynoird, E. BoresjzaWysocka, S.K. Brown, and H.S. Aldwinckle. 2000. Effect of untranslated leader sequence of AMV RNA4 and signal peptide of pathogenesis-related protein $1 \mathrm{~b}$ on attacin gene expression and resistance to fire blight in transgenic apple. Biotechnol. Lett. 22:373-381.

Kuehnle, A.R. and F.-C. Chen. 1994. Genetic Transformation in Anthurium, p. 215-225. In: Bajaj, Y.P.S. (ed.). Biotechnology in agriculture and forestry. Vol. 29. Plant protoplasts and genetic engineering V. Springer-Verlag, Berlin, Germany.

Kuehnle, A.R., F.-C. Chen, and N. Sugii. 1992. Somatic embryogenesis and plant regeneration in Anthurium andraeanum Linden ex André hybrids. Plant Cell Rep. 11:438-442.

Kuehnle, A.R., F.-C. Chen, and N. Sugii. 2001. Transgenic Anthurium, p. 3-15. In: Bajaj, Y.P.S. (ed.). Biotechnology in agriculture and forestry. Vol. 48. Transgenic crops III. Springer-Verlag, Berlin, Germany.

Kuehnle, A.R., T. Fujii, F.-C. Chen, A. Alvarez, N. Sugii, R. Fukui, S.L. Aragon, and J.M. Jaynes. 2004. Peptide biocides for engineering bacterial blight tolerance and susceptibility in cutflower Anthurium. HortScience 39:1327-1331.

Lazo, G.R., P.A. Stein, and R.A. Ludwig. 1991. A DNA transformation-competent Arabidopsis genomic library in Agrobacterium. Bio/Technology 9:963-967.

Lin, R.C., Z.S. Ding, L.B. Li, and T.Y. Kuang. 2001. A rapid and efficient DNA minipreparation suitable for screening transgenic plants. Plant Mol. Biol. Rpt. 19:379a-379e.

Murashige, T. and F. Skoog. 1962. A revised medium for rapid growth and bioassays with tobacco tissue cultures. Physiol. Plant. 15:473-497.

NASS. 2009. Hawaii Agricultural Statistics Service, 2008. Hawaii flowers and nursery products annual summary. Hawaii Department of Agriculture, U.S. Department of Agriculture, Honolulu, HI.

Porsch, P., A. Jahnke, and K. Düring. 1998. A plant transformation vector with a minimal T-DNA II. Irregular integration patterns of the T-DNA in the plant genome. Plant Molec. Biol 37:581-585.

Statistix 7 for Windows. 2000. Analytical software. $<$ http://www.Support@statistix.com>.

Urwin, P.E., M.J. McPherson, and H.J. Atkinson. 1998. Enhanced transgenic plant resistance to nematodes by dual proteinase inhibitor constructs. Planta 204:472-479.

Wei, H., H.H. Albert, and P.H. Moore. 1999. Differential expression of sugarcane polyubiquitin genes and isolation of promoters from two highlyexpressed members of the gene family. J. Plant Physiol. 155:513-519. 